\title{
Is a European market for pension products within reach? A Dutch conclusion with a UK perspective \\ Received: 7th November, 2003
}

\section{Henriëtte de Lange}

is a Dutch pensions lawyer. In 2002 she started her own pension consultancy firm with Emilie Schols, Schols \& de Lange, which is based in Leiden and specialises in all matters concerning the legal and tax aspects of pensions and life assurance. Prior to this she worked in the tax and legal department of a life insurance company and, thereafter, as a manager at PricewaterhouseCoopers.

\section{Graham Wrightson}

is a solicitor in the pension and international benefits practices of Hammonds. His expertise includes aspects of pension scheme investment and European and international pensions, with a particular interest in the Netherlands.

He has written articles on pensions law for numerous publications and is the author of a chapter on employee benefits in the Netherlands for 'International Pensions and Benefits' published by Tolleys. He is a member of the International Pension and Employee Benefits Lawyers Association (IPEBLA), and of the Association of Pension Lawyers.

\begin{abstract}
This paper aims to explore the implications, from a Dutch perspective, of the decision in the Skandia case for cross-border pension provision. In particular, the paper questions whether the current fiscal policy in the Netherlands still forms an obstacle to the provision of old-age pensions by foreign EU insurers who wish to offer their products on the Dutch market.
\end{abstract}

Keywords: cross-border pension provision; EU treaty rights; taxation; deduction of premiums; foreign insurers; endowment insurance; old-age insurance; the Netherlands

Graham Wrightson Hammonds, 7 Devonshire Square, Cutlers Gardens, London EC2M 4YH, UK.

Tel: +44 (0)870 839 1123; Fax: +44 (0)870 4582674 ; e-mail: graham.wrightson@ hammonds.com

\section{Introduction}

On 26th June, 2003, the European Court of Justice (ECJ) delivered its decision in the Skandia ${ }^{1}$ case and, in the process, went a step further than it did in the Danner ${ }^{2}$ decision of October 2002. In contrast to the Bachmann, ${ }^{3}$ Wielockx, ${ }^{4}$ Safir ${ }^{5}$ and Danner ${ }^{2}$ cases, it was not an individual who felt that his freedom was being restricted but, instead, it was an insurer, Skandia, which was being disadvantaged by Swedish law. Skandia, a Swedish life assurance company, could be described as a trailblazer in removing fiscal obstacles in the European Union (EU)
(Jessica Safir's policy having also been taken out with this insurer).

\section{The facts of the Skandia case}

These facts of the Skandia ${ }^{1}$ case are as follows. Mr Ola Ramstedt, who worked for Skandia, agreed with his employer that part of his pension would be insured with the Danish, German or UK subsidiary of Skandia. These subsidiary companies would then provide policies which complied with the Swedish law on pension provision. Insofar as it relates to supplementary pension provision, Swedish law draws a distinction between 
old-age insurance and endowment insurance. To be recognised as old-age insurance, an insurance policy has, among other things, to be taken out with an insurer established in Sweden. An insurance policy which is not taken out with a Swedish insurer can, nevertheless, constitute pension insurance provided one of the following conditions is satisfied:

- the insurance policy relates mainly to the provision of an old-age, invalidity or survivor's pension and the taxable person is resident abroad when the contract is entered into, in a country whose tax system allows a right to deduct or other tax relief;

- the employer pays insurance premiums while the insured lives or works in another country and that payment is not counted as taxable income of the person insured; or

— in light of the particular circumstances of the case, the tax authority authorises the insurance policy to be treated as pension insurance.

An insurance policy which does not satisfy the above conditions is considered to be endowment insurance. In terms of direct taxation, the two types of insurance are subject to different rules on deduction of tax. Premiums which an employer pays under old-age pension insurance are immediately deductible. Pension payments which are subsequently made are subject to income tax in their entirety in the hands of the retired employee who is the beneficiary of the policy. Premiums paid in relation to endowment insurance are not immediately deductible by an employer. That said, an employer has a right to deduct the amount of premiums paid where he has contractually undertaken to the employee to do so, but that deduction can only be made at the time the pension is actually paid to the employee. In the hands of the employee, the benefits constitute taxable earned income. It therefore makes no difference to the employee whether the insurance is endowment insurance or old-age insurance; the tax consequence is the same in both cases.

Before concluding the insurance contract, Mr Ramstedt and Skandia both asked the Swedish Council for Advance Tax Rulings for answers to a number of questions. Two of the questions amounted to the following:

1 If Skandia is entitled to deduct the premiums for an insurance policy taken out with one of its foreign subsidiaries from taxable income, when could that deduction be made?

2 Would the answer to the first question be different depending on whether or not the insurance companies were obliged to provide the Swedish tax authorities with information about the amounts which would be paid to $\mathrm{Mr}$ Ramstedt under the insurance policy?

The Council for Advance Tax Rulings' response was that Skandia was only entitled to deduct premiums paid at the time the pension was actually paid, not at the time the premiums were paid. There would be a tax disadvantage for Skandia if premiums were paid to a foreign insurer. Ramstedt and Skandia appealed against this decision to the Swedish Regeringsrätten. The Regeringsrätten referred the following question to the ECJ:

\footnotetext{
'Are the provisions of Community law on the freedom of movement for persons, services and capital, in particular Article 49 EC, in conjunction with Article $12 \mathrm{EC}$, to be interpreted as meaning that they preclude the application of national tax rules under which an insurance policy issued by an
} 
insurance company in the UK, Germany or Denmark which meets the conditions laid down in Sweden for occupational pension insurance, apart from the condition that the policy must be issued by an insurance company operating in Sweden, is treated as an endowment insurance policy with income tax effects which, depending on the circumstances in the individual case, may be less favourable than the tax effects of an occupational pension policy?'

\section{The ECJ's decision}

The ECJ states at the outset that the question in hand is how national requirements limit the freedom to provide services. The fact that an employer suffers a financial disadvantage because the right to deduct is postponed until the time that pension benefits are paid to the employee, could dissuade the employer from taking out occupational pension insurance with institutions established in another member state other than Sweden. Consequently, non-Swedish institutions would be dissuaded from offering their services on the Swedish market.

Just as in the Danner ${ }^{2}$ case, the ECJ demonstrates the importance it attaches to foreign institutions being treated in the same way as the national institutions of a member state. Looking at the situation in the Netherlands, it can be argued on the basis of this decision that the current requirement for foreign insurers to provide some form of security before their products are treated as deductible by the Dutch taxpayer, constitutes an obstacle to the freedom to provide services and, as such, conflicts with European law.

\section{Justifications relied on}

During the proceedings, Sweden and Denmark put forward four reasons to justify their approach: fiscal cohesion, fiscal controls, preservation of the tax base and competitive neutrality.

\section{Fiscal cohesion}

Although, since Bachmann, ${ }^{3}$ the ECJ has found no further instance where fiscal cohesion might apply, the Swedish and Danish governments raised the point once again. Both countries argued that, although the right to deduct did not apply to the taxpayer who was liable to taxation, the tax advantages and disadvantages of the pension policy affected, in practice, only the employee who was the beneficiary of the policy. The pension insurance premium paid by the employer constituted de facto part of the employee's remuneration. If the employer did not pay the premium, the employee's net remuneration would have been higher such that he would have been able to pay the premium himself. The fact that the contribution to the pension policy was paid by the employer and not by the employee was merely a technicality.

The ECJ saw no merit in this line of reasoning. It stated that the Bachmann ${ }^{3}$ judgment was based on the finding that, under Belgian law, there was a direct connection between the deductibility of contributions and the liability to tax on amounts paid by insurers. In Skandia no such connection existed. Indeed, under the Swedish system, an employer who took out an insurance policy with an insurer established in another member state had to wait until pension benefits were paid to his employee before he had a right to deduct. There was no compensatory measure to offset the disadvantage he suffered compared with an employer who took out comparable insurance with a company established in Sweden. There was no question of fiscal cohesion. 


\section{The effectiveness of fiscal controls}

With regard to this point, we can be fairly brief. The complaint of the Danish and Swedish governments that their legislation was justified by the need to have adequate and effective fiscal controls in place was brushed aside by the ECJ in almost the same language as in Danner. ${ }^{2}$ The message is clear: although the ECJ of course puts it more conservatively, it pretty much comes down to saying that 'There is a directive relating to mutual co-operation between relevant tax authorities, so make use of that'. In addition, the ECJ indicates that it is possible to request the desired information directly from either the employer or from the employee himself. There are methods which are less restrictive to the freedom to provide services than is currently the case in Sweden. Unfortunately, the ECJ, just as in Danner, ${ }^{2}$ does not go any further in saying which methods it considers to be less restrictive. In the Netherlands, the legislator has, among other things, elected to use the method of a contract which a foreign insurer must enter into with the Dutch tax authorities before that insurer's products are deductible by Dutch resident taxpayers. Based on the Skandia ${ }^{1}$ decision, it cannot be said with any certainty that such a contract would be considered by the ECJ to be less restrictive to the point that it did not form a barrier to the provision of services.

\section{Preservation of the tax base}

According to the Swedish government, the requirement of establishment in Sweden was justified by the risk that taxable property might 'disappear'. The Danish government suggested that the ECJ had, in Safir, ${ }^{5}$ held that the protection of the tax base was a public interest requirement which could form a justification for indirectly discriminatory tax rules. The ECJ struggled with this argument, and stated that, although there might be an ultimate fiscal advantage in the form of a lower level of taxation in the member state in which those offering such services were established, this could not be used by another member state to treat recipients of those services established in its territory in a less favourable way. Such compensatory tax arrangements would prejudice the foundations of the single market.

\section{Competitive neutrality}

This justification (which was not considered in Danner ${ }^{2}$ ) was based on some complicated reasoning put forward by the Swedish government which the ECJ, following the opinion of the Advocate General, politely points out is too difficult to follow. It is possible that, in explaining the Swedish system, something has fallen by the wayside so that those who are not familiar with the system would find the line of argument difficult to follow. The importance of the point that the Swedish government wanted to make also escapes us. In any case, the ECJ quite forcefully disposes of the justification. It states that considerations as to equality of competition between different methods of guaranteeing occupational pensions could not be upheld at the cost of restricting the free movement of services.

\section{The ECJ's conclusion}

The ECJ finishes its decision as follows:

\footnotetext{
'Article 49 EC precludes an insurance policy issued in another Member State by an insurance company established in that state and which meets the conditions laid down in national law for occupational pension
} 
insurance (apart from the condition that the policy must be issued by an insurance company operating in the national territory) from being treated differently in terms of taxation with income tax effects which, depending on the circumstances of the case, could be less favourable.'

\section{European market for pension provision}

Now that it appears to be settled law that premiums can be paid to a foreign insurer which issues policies conforming to the national law of the person liable for tax and who is claiming the deduction, there would appear to be nothing preventing foreign insurers from offering pension products on the Dutch market. It is well known that, in some countries, there are lower cost structures than the majority of Dutch insurers could manage to the extent that, for individual old-age pension provision in particular, there is very likely to be a demand for these products from foreign providers.

Because of the directives on life insurance and the implementation of them, it is attractively simple for a foreign insurer to gain access to the Dutch market. A foreign EU insurer wishing to offer insurance products in the Netherlands is required to notify its own supervisory body of that fact. The foreign supervisory body then passes details to the Pensioen- \&

Verzekeringskamer (PVK) which has only limited scope to object. The foreign EU insurer remains under the supervision of the foreign supervisory body. That body is then required to ensure that the insurer continues to comply with the applicable laws and regulations of the country concerned. The PVK can only impose some general requirements on a foreign insurer offering products in the Netherlands. For example, the insurer is required to comply with the duty to provide information to the same extent that that duty applies to Dutch insurers. In this respect, consideration needs to be given to ensuring compliance with the 'risk and return' Code and the provision of financial information. The PVK is unable to impose any additional demands as to the tariff payable provided that tariff complies with the law and regulations of the country where the foreign insurer is situated.

To ensure that premiums relating to a foreign insurer's pension products are in fact deductible for a Dutch employer, the insurer is also required to enter into a contract with the Dutch tax authority. As already noted, it cannot be said with any certainty that the ECJ would not find such a contract to be an obstacle from the point of view of freedom to provide services. This will greatly depend on the content of the contract; if it is limited to requiring the foreign insurer to regularly provide information which is important in determining the amount of tax to be levied, it seems to us that this would not be readily classified as being too restrictive. Dutch insurers are also required to provide this information. If, the information that is asked for creates a heavy burden on the foreign EU insurer, it could raise the spectre of a restriction which conflicts with European law.

\section{Final obstacle}

It is fairly certain that the security which a foreign insurer is required to provide could be too much to ask. This is the final fiscal obstacle. The necessity to provide such security is no longer relevant because, on 30th June, 2002, the Directive on recovery of tax was extended. With the help of this Directive, a competent tax authority has various methods at its disposal for recovery of tax. A tax authority no 
longer needs to be concerned, within Europe, that it will not receive what is due to it. The assurances which a foreign insurer must put in place before premiums which were paid to it in the Netherlands can be deducted have now become redundant.

It would be to the credit of the Dutch Ministry of Finance if it were to use the '2004 Tax Plan' to abolish the strange practice of requiring security. Just let it disappear without a trace. If the Ministry of Finance is not so sporting, it will take a brave insurer to challenge the security requirement before the ECJ. It would not surprise us if a Dutch judge, even without putting a prejudicial question, reached the conclusion that the provision of security was a requirement which was in direct conflict with European law. In March 2003 the High Court in the Hague reached the decision that the tax (of 60 per cent charged when a 'personal pension company' moves abroad) qualifies as a restriction on the freedom to establish abroad, so there is already a decision in this area.

From a tax perspective, in principle, the path is completely open for foreign insurers to enter the Dutch market. Assuming that the conditions of the contract with the tax authority are reasonable, the contract should not be an obstacle. Any security which is required may well be an obstacle but that condition will eventually disappear. A foreign insurer which does not mind conforming to Dutch legal requirements can now start exploring the Dutch market and we are particularly keen to learn who will be first.

\section{The UK perspective}

The Skandia ${ }^{1}$ case is interesting from the UK perspective given that it involved Skandia's UK subsidiary. If it is now possible for premiums to be paid by a Swedish employer for a policy taken out in the UK then there is apparently an open playing field for a UK insurer to ask for the same to be done from the Netherlands into the UK. The question as to which insurer is likely to attempt this first is an interesting one - there are several UK insurers who might well have an eye on the Dutch market at the present time.

While the EU (and, more particularly, the ECJ) is striving to ensure that cross-border pension provision becomes a reality, it is (as has already been noted) national legislation underlying the broader legal principles which poses possibly the greatest problem. The solvency hurdle which a UK insurer may be required to overcome under Dutch law, to allow a Dutch employer to fully deduct premiums paid to the UK insurer for a policy taken out in the UK, may be viewed by many insurers as a bridge too far. However, recent case law from the ECJ rather suggests that, if a UK insurer were to take issue with the Dutch requirements, those requirements are unlikely to be upheld. A lengthy court case could result in an own goal for the Dutch government as there appears to be less and less justification for imposing additional requirements on insurers in today's European market.

Assuming, therefore, that UK insurers are in a favourable position to offer policies to the Dutch consumer, is this likely to be attractive? It is relatively well known that the costs of insurance policies in the Netherlands are higher than in the UK. On this ground alone, there is a clear incentive for the Dutch consumer to take out a policy with a UK provider, particularly if the tax consequences of doing so are going to be for all intents and purposes cost-neutral. The question then is one of 'trust and confidence' in the provider. 
Will a Dutch consumer readily put his toe in the water of the UK insurance industry? After all, policies will need to be translated and the average Dutch consumer may have reservations about the small print in insurance contracts which is notoriously difficult to understand even for native English speakers! UK insurers are going to need to think long and hard about how to deal with the practicalities of offering their policies to consumers in other EU countries.

A second issue which arises is that of conflict of laws. Ordinarily, the law governing the contract would be the law under which you would expect any disputes to be resolved. If the policy were governed by English law, insurers in the UK might be able to avoid paying out on a policy in circumstances where this would not be possible in the Netherlands. Take the example of a policyholder in the UK who takes out a life insurance policy but fails to declare a heart condition. The policyholder is subsequently involved in a car crash and dies from those injuries, the heart condition playing no part in the death. In the UK, the non-declaration of the heart condition could be relevant to the risk insured and classically it may be possible for a UK insurer to seek to avoid paying out on the policy as a consequence. The Netherlands' approach to the risk is more likely to be that the insurer will have to pay out. A UK insurer will therefore have to weigh up carefully just how far it wishes to go in conforming its policy to Dutch law. Whatever the cause of any disparity in the application of the relevant law, the question is then whether a specialist UK insurance issue would prevail over the Dutch approach; the UK company providing the policy and the person taking out the policy may be considered to have unequal bargaining positions. It may then fall to the provider to make Dutch clients specifically aware of this particular oddity, failing which the contract might be considered unreasonable. Again, the hurdle of dealing with potential conflict issues and the possibility of providing additional explanatory literature may be discouraging to UK insurers.

For those insurers that decide to take the step, there may well be rich pickings to be had. The Dutch market is competitive but Dutch consumers may well find the lower costs levied by UK insurers on their products to be quite attractive. The ECJ is clearly taking the line that cross-border provision of insurance policies (and pensions) should be unhindered by taxation issues. National preferences and conflict of laws still raise some interesting issues. There are certainly opportunities for insurers in the brave new world of EU pensions and we may not have heard the last of Skandia's name in this respect...

\section{References}

1 Forsakringsaktiebolaget Skandia \& Ola Ramstedt $v$ Riksskatteverket, Case C-422/01, ECJ (Fifth Chamber) 26th June, 2003.

2 Rolf Dieter Danner, Case C-136/00, ECJ (Fifth Chamber) 3rd October, 2002.

3 Hanns-Martin Bachmann v Belgium, Case C-204/90, [1992] ECR I-249.

4 Wielockx $v$ Inspecteur der Direct Belastingen, Case C-80/94, [1995] ECR I-2493.

5 Safir $v$ Skattemyndigheten i Dalarnas Lan, Case C-118/96, [1998] ECR I-1897. 